\title{
Physicochemical and Functional Properties of Chemically Pretreated Ndou Sweet Potato Flour
}

\author{
Khuthadzo Ngoma, Mpho E. Mashau $\mathbb{D}^{D}$, and Henry Silungwe \\ Department of Food Science and Technology, School of Agriculture, University of Venda, Private Bag X5050, Thohoyandou 0950, \\ South Africa \\ Correspondence should be addressed to Mpho E. Mashau; mpho.mashau@univen.ac.za
}

Received 20 February 2019; Revised 16 August 2019; Accepted 5 September 2019; Published 3 November 2019

Academic Editor: Vita Di Stefano

Copyright (c) 2019 Khuthadzo Ngoma et al. This is an open access article distributed under the Creative Commons Attribution License, which permits unrestricted use, distribution, and reproduction in any medium, provided the original work is properly cited.

\begin{abstract}
Sweet potato (Ipomoea batatas Lam) is a nutritious crop abundant in calories and bioactive compounds such as beta-carotene, ascorbic acid, polyphenols, and dietary fibre. This study investigated the effect of pretreatments on the physicochemical and functional properties of Ndou sweet potato (NSP) flour. Flour samples were prepared by randomly assigning NSP slices to two treatments (citric acid and sodium metabisulphite) at 5,10 , and $15 \mathrm{~g} / \mathrm{L}$ concentration for $10 \mathrm{~min}$. Distilled water was used as control. The moisture content $(7.70 \%)$ of NSP flour treated with citric acid was significantly $(p<0.05)$ higher than that of the flour treated with sodium metabisulphite (5.54\%) as the concentration level increased. The treatments did not significantly $(p<0.05)$ affect the protein and fat contents of the NSP flour and protein increased from 2.54 to $2.82 \%$, while fat decreased from 0.69 to $0.61 \%$. Sodium metabisulphite treated samples had a higher $L^{*}$ value, ash, and $\mathrm{pH}$ level than citric acid treated samples. However, $\mathrm{pH}$ was slightly decreased by both treatments from 6.05 to 5.09. Citric acid treated samples had higher $a^{*}$ and $b^{*}$ values than sodium metabisulphite treated samples. In terms of the functional properties of NSP flour, the treatments significantly $(p<0.05)$ affected the water absorption capacity, viscosity, swelling power, solubility index, and thermal properties although the bulk density and least gelation concentration were not significantly $(p>0.05)$ affected. Sodium metabisulphite was very effective in improving physicochemical and functional properties of NSP flour as compared to citric acid. The findings of this study show the possibilities of using NSP flour in food systems as gelling agent, fat replacer, and thickeners.
\end{abstract}

\section{Introduction}

Sweet potato (Ipomoea batatas Lam) has been identified as a food security crop because it contains reasonable amounts of bioactive compounds such as b-carotene, ascorbic acid, polyphenols, dietary fibre as well as vitamins, minerals, and proteins $[1,2]$. The crop is still underutilised although it is rich in starch and carbohydrates and its flour can be used in different industrial applications $[3,4]$. The most commonly obtainable sweet potato varieties have purple, yellow, and white root tubers because of the distinct contents of phenolic compounds and pigments in their root tubers [5-7]. Processing of sweet potato roots into food products such as flour or chips can be used as one of the ways to address the challenges faced with storing and transporting the raw sweet potato roots in developing countries. Ndou is one of the sweet potato cultivars grown in Limpopo province, South Africa. Ndou sweet potato
(NSP) cultivar is high-yielding and is mostly bred by the Agricultural Research Council in South Africa. It has a dark cream skin colour and flesh colour as well as a round and long elliptic storage root shape.

There are several drawbacks that have been identified during the preparation of sweet potato products and one of these is discoloration which affects the quality of products [8]. Various methods such as blanching with sodium tripolyphosphate $\left(\mathrm{Na}_{5} \mathrm{P}_{3} \mathrm{O}_{10}\right)$ and sodium metabisulphite $\left(\mathrm{Na}_{2} \mathrm{~S}_{2} \mathrm{O}_{5}\right)$ have been used to prevent or eliminate discolouration of sweet potato flour $[9,10]$. Processing sweet potato into flour extends its storage life and value. The flour has different applications in the food industry such as serving as a thickening agent in gravy, soup, bakery products, and fabricated snacks [10]. However, high quality sweet potato flour will be needed if the flour is going to be incorporated into other food products. However, there is lack of knowledge and understanding of 
physicochemical and functional properties of NSP and the effect that the different processing methods have on these properties and functionality of the different components. The closure of this knowledge gap may broaden the applications of NSP flour within the food industry. Sodium metabisulphite and citric acid have been used to pretreat sweet potato products, but their effects on NSP flour have not been revealed. Therefore, the aim of this work was to determine the effect of application of chemical agents: sodium metabisulphite and citric acid as pretreatments to fresh cut NSP on the physicochemical and functional properties of its flour. Processing sweet potato into flour, which is an intermediate product, is one of the ways of minimizing post-harvest losses and increasing the utilization of sweet potatoes [11].

\section{Materials and Methods}

2.1. Materials. Fresh NSP (Ipomoea batatas Lam) tubers were purchased from ARC in Pretoria, Gauteng province, South Africa. Chemicals used in this study were commercially purchased from Sigma-Aldrich, Johannesburg, South Africa.

2.2. Experimental Design. The experiment was set up as a completely randomised design and the pretreatments of NSP flour with sodium metabisulphite and citric acid at different concentrations were considered. The factor levels were: distilled water $5,10,15 \mathrm{~g} / \mathrm{L}$ of sodium metabisulphite for 10 min (experiment 1 ) and 5, 10, 15 g/L of citric acid for $10 \mathrm{~min}$ (experiment 2). Each experiment was done in triplicate.

2.3. Flour Production. Ndou sweet potato tubers were weighed, washed, peeled, and cut into $4 \mathrm{~mm}$ size. Sliced sweet potatoes were divided into two batches, and randomly assigned to two treatments (chemical agents) as follows: sodium metabisulphite and citric acid at 5, 10, and $15 \mathrm{~g} / \mathrm{L}$ concentration for $10 \mathrm{~min}$. The untreated (control) slices were immersed in distilled water for $10 \mathrm{~min}$ at room temperature. The sweet potato slices immersed in the two chemical solutions were allowed to drain for $2 \mathrm{~min}$ after which the pretreated and control NSP slices were put on a tray and oven dried for 10 $\mathrm{h}$ at $70^{\circ} \mathrm{C}$. The pretreated and control NSP slices were milled into flour (Figure 1) after drying. Approximately an 80 mesh sieve was used to screen the NSP flour samples; they were stored in polyethylene bags and then kept in the refrigerator at $4^{\circ} \mathrm{C}$ prior to use.

\subsection{Assessment of the Physicochemical and Functional Properties of NSP Flour}

2.4.1. Proximate Analysis. All proximate analyses were done in triplicate. The moisture, ash, protein and fat contents and crude fibre of NSP flour were determined using standard methods of Association of Official Analytical Chemist (AOAC) [12]. The moisture content of NSP flour was determined according to the AOAC method 945.32 with oven drying at $105^{\circ} \mathrm{C}$ for $3 \mathrm{~h}$. Ash content was determined using the muffle furnace according to the official method 923.03. The crude protein was determined using the Kjeldahl method, AOAC method

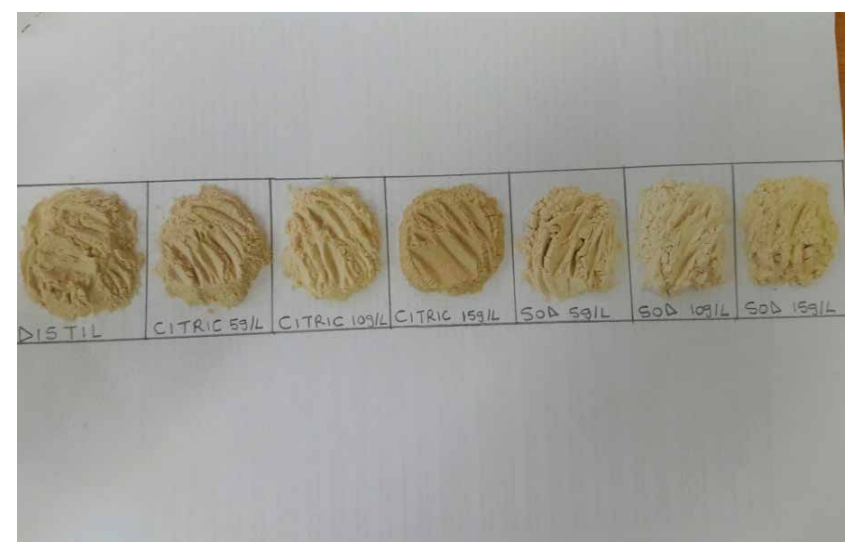

Figure 1: Ndou sweet potato flour.

978.02, and $6.25 \times \mathrm{N}$ was used to multiply the nitrogen content in order to obtain protein percentage. The fat content was determined according to the AOAC method 920.39.

2.4.2. Colour Analysis. The colour of NSP flour samples was measured using a Hunterlab LabScan XE Spectrophotometer CIELAB. The black and white plates were used to calibrate the spectrophotometer and zero calibration followed. The NSP flour was put in a glass cell and placed above the light source of the instrument and colour coordinate values $L^{*}$ (Lightness/ darkness), $a^{*}$ (redness/green) and $b^{*}$ (yellowness/blue) were recorded [13].

2.4.3. Determination of $p H$. About $10 \mathrm{~g}$ of each sample of NSP flour samples was mixed with $100 \mathrm{~mL}$ of distilled water in order to measure the $\mathrm{pH}$ values of flour. The mixture was left at room temperature for $30 \mathrm{~min}$. The $\mathrm{pH}$ meter that had already been standardised with buffer solutions of $\mathrm{pH} 4.0$ and 7.0 was then used to measure the $\mathrm{pH}$ values of the supernatant.

2.4.4. Water Absorption Capacity. The method of Onwuka [14] was followed to measure the water absorption capacity of NSP flour. Approximately $1 \mathrm{~g}$ of flour sample was weighed in a conical graduated centrifuge tube and dispersed in $10 \mathrm{ml}$ of water. The mixture was thoroughly shaken for $1 \mathrm{~min}$ at room temperature. The sample was allowed to stand for $30 \mathrm{~min}$ before it was centrifuged at 5,000 $\times \mathrm{g}$ for $30 \mathrm{~min}$. The volume of free water was determined directly from the centrifuge tube. The amount of the absorbed water was multiplied by the density of water $(1 \mathrm{~g} / \mathrm{ml})$ and results were expressed as $\mathrm{g} / 100 \mathrm{~g}$.

2.4.5. Bulk Density. The method of Konak et al. [15] was followed to determine the bulk density of the flour. Approximately $50 \mathrm{~g}$ of NSP flour was weighed into a $100 \mathrm{ml}$ graduated measuring cylinder and the cylinder was gently tapped continuously until the contents were tightly packed. The bulk density was calculated as weight of NSP flour (g) divided by NSP flour volume $\left(\mathrm{cm}^{3}\right)$.

2.4.6. Least Gelation Concentration. The method of Sathe et al. [16] was adopted to determine the least gelation concentration (LGC) of NSP flour. Sample suspensions of $2-20 \%(w / w)$ of 
TABLE 1: Proximate composition of NSP flour.

\begin{tabular}{|c|c|c|c|c|c|c|c|}
\hline \multirow{3}{*}{ Proxi (\%) } & \multicolumn{7}{|c|}{ Treatments $(\mathrm{g} / \mathrm{L})$} \\
\hline & \multicolumn{2}{|c|}{ Distil } & \multicolumn{3}{|c|}{$\mathrm{C}_{6} \mathrm{H}_{8} \mathrm{O}_{7}$} & \multicolumn{2}{|c|}{$\mathrm{Na}_{2} \mathrm{~S}_{2} \mathrm{O}_{7}$} \\
\hline & & 5 & 10 & 15 & 5 & 10 & 15 \\
\hline Moisture & $6.50 \pm 0.71^{\mathrm{bc}}$ & $5.98 \pm 0.14^{\mathrm{c}}$ & $7.15 \pm 0.56^{\mathrm{ab}}$ & $7.70 \pm 0.13^{\mathrm{a}}$ & $6.61 \pm 0.02^{\mathrm{b}}$ & $6.85 \pm 0.17^{\mathrm{b}}$ & $5.54 \pm 0.71^{\mathrm{d}}$ \\
\hline Ash & $1.03 \pm 0.03^{c}$ & $1.04 \pm 0.02^{\mathrm{c}}$ & $1.08 \pm 0.07^{\mathrm{c}}$ & $1.07 \pm 0.07^{\mathrm{c}}$ & $1.77 \pm 0.13^{\mathrm{b}}$ & $2.54 \pm 0.13^{\mathrm{a}}$ & $0.70 \pm 0.05^{\mathrm{d}}$ \\
\hline Protein & $2.64 \pm 0.15^{\mathrm{ab}}$ & $2.54 \pm 0.02^{\mathrm{b}}$ & $2.54 \pm 0.04^{\mathrm{b}}$ & $2.72 \pm 0.08^{\mathrm{a}}$ & $2.07 \pm 0.07^{\mathrm{c}}$ & $2.62 \pm 0.16^{\mathrm{b}}$ & $0.68 \pm 0.03^{\mathrm{d}}$ \\
\hline Fat & $0.69 \pm 0.02^{\mathrm{b}}$ & $0.68 \pm 0.01^{\mathrm{b}}$ & $0.65 \pm 0.01^{\mathrm{b}}$ & $0.61 \pm 0.02^{\mathrm{b}}$ & $2.87 \pm 0.04^{\mathrm{a}}$ & $2.82 \pm 0.17^{\mathrm{a}}$ & $0.68 \pm 0.03^{\mathrm{b}}$ \\
\hline
\end{tabular}

Results are mean \pm standard deviation. Values in the same row followed by different letters are significantly different $(p<0.05)$. Distil: distill water, $\mathrm{C}_{6} \mathrm{H}_{8} \mathrm{O}_{7}=$ citric acid, $\mathrm{Na}_{2} \mathrm{~S}_{2} \mathrm{O}_{7}=$ sodium metabisulphite, and Proxi = proximate composition .

each NSP flour samples were prepared in $10 \mathrm{ml}$ distilled water and the suspension was transferred into a test tube. The test tube was heated for $1 \mathrm{~h}$ in boiling water and a bath of cold water was used to rapidly cool it. All the test tubes were further cooled in water at $4^{\circ} \mathrm{C}$ for $2 \mathrm{~h}$. Inversion was done for each tube one after the other. The LGC was the concentration when the sample did not fall down or slip when inversion was done on the test tube.

2.4.7. Viscosity. Approximately 10 gram of the NSP flour sample was mixed with $90 \mathrm{ml}$ water at $30^{\circ} \mathrm{C}(10 \%$ slurry, w/v) and allowed to hydrate for $30 \mathrm{~min}$ with occasional stirring. Brookfield viscometer (Model RV, Brookfield Engineering Inc., Stoughton, USA) was used to measure the viscosity of the samples.

2.4.8. Swelling Capacity and Starch Solubility Index. The method of Anyasi et al. [17] was adopted to determine the swelling capacity and solubility index of the NSP flour samples whereby about $1 \mathrm{~g}$ of flour was mixed with $10 \mathrm{~mL}$ of distilled water in a centrifuge tube and heated at $80^{\circ} \mathrm{C}$ for $30 \mathrm{~min}$ with constant stirring. The tubes were removed and cooled to room temperature. Upon cooling, samples were centrifuged for 15 $\mathrm{min}$ at $2200 \mathrm{rpm}$. The supernatant was decanted and weight of the puree was then determined. For solubility index, the supernatant obtained from the swelling power was decanted in a preweighed evaporation dish and dried to constant weight in the oven and calculated.

2.4.9. Thermal Properties. The thermal properties of NSP flour samples were investigated as described by Sun et al. [18] with some modifications using a differential scanning calorimeter (DSC, DSC 4000, Perkin-Elmer, Shelton, CT, USA). Approximately $1 \mathrm{mg}$ of NSP flour was mixed with $1 \mathrm{ml}$ of distilled water placed into aluminium hermetic pans and samples were allowed to equilibrate for $1 \mathrm{~h}$ prior to analysis. An empty pan was used as reference. Calorimeter scan conditions were set as follows: samples were heated from 25 to $120^{\circ} \mathrm{C}$ with a heating rate of $10^{\circ} \mathrm{C} / \mathrm{min}$. The parameters evaluated were: Onset temperature $\left(T_{0}\right)$, peak time $(T p)$, conclusion temperature $\left(T_{c}\right)$ and enthalpy $(\Delta H)$. Pyris software (Perkin-Elmer, Shelton, CT, USA) was used for calculation of obtained data.

2.5. Data Analysis. All measurements were done in triplicate. The data collected were subjected to statistical analysis to test for variance (ANOVA) using SPSS version 23.0 with Duncan test at $p<0.05$ level of significance.

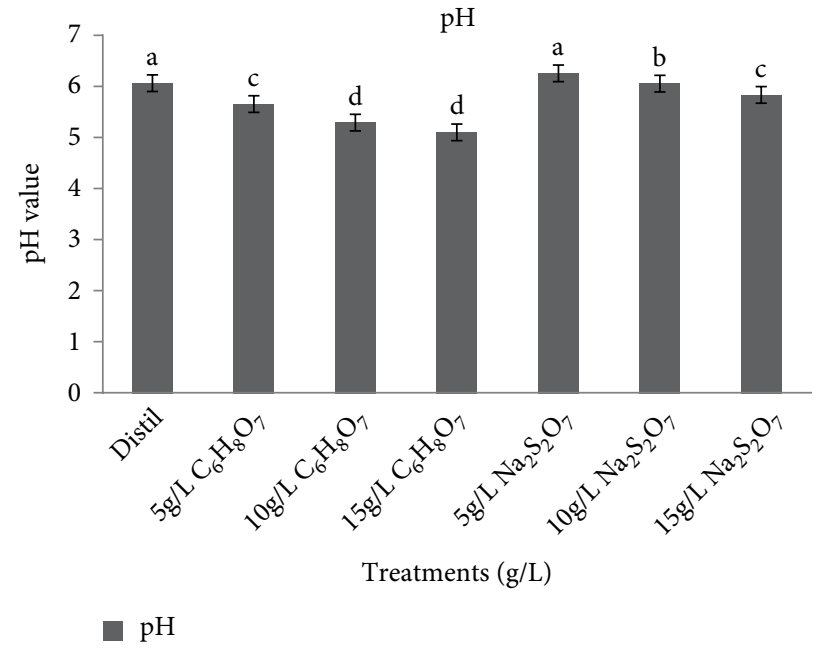

FIGURE 2: Effect of pretreatment on $\mathrm{pH}$ value of $\mathrm{Ndou}$ sweet potato flour. Distil = distilled water, $\mathrm{C}_{6} \mathrm{H}_{8} \mathrm{O}_{7}=$ citric acid and $\mathrm{Na}_{2} \mathrm{~S}_{2} \mathrm{O}_{7}=$ sodium metabisulphite.

\section{Results and Discussion}

3.1. Physicochemical Properties of NSP Flour. The moisture content of untreated (control) NSP flour was $6.50 \%$ and it ranged from $5.54 \%$ to $7.70 \%$ for variously treated samples as shown in Table 1. This range is similar to one reported by Haile et al. [19] for an orange fleshed sweet potato cultivar. There was a significant difference of $p<0.05$ in the moisture content of citric acid treated samples at different levels. A higher level of $7.70 \%$ of moisture content was obtained from citric acid pretreatment of $10 \mathrm{~g} / \mathrm{L}$ concentration, while the lowest moisture content of $5.54 \%$ was obtained for sodium metabisulphite pretreatment of $15 \mathrm{~g} / \mathrm{L}$ concentration. This might be due to the ability of sodium metabisulphite to cause dehydration in sweet potato slices. The lower moisture content of the NSP flour samples will give a better shelf life and denser nutrient [20].

All the sweet potato flour samples had the moisture content within a favourable range for effective storage of the flour with minimal risk of microbial contamination. The moisture content of flours below $14 \%$ is capable of resisting microbial growth resulting in shelf stable flour [21]. The physicochemical component is one of the principal factors that dictate flour quality, especially moisture [22, 23]. At 
TABLE 2: Colour attributes of NSP flour samples.

\begin{tabular}{lccccccc}
\hline \multirow{2}{*}{ Color attributes } & \multicolumn{5}{c}{ Treatment $(\mathrm{g} / \mathrm{L})$} \\
& Distil & 5 & $\mathrm{C}_{6} \mathrm{H}_{8} \mathrm{O}_{7}$ & & \multicolumn{2}{c}{$\mathrm{Na}_{2} \mathrm{~S}_{2} \mathrm{O}_{7}$} & 15 \\
\hline$L^{*}$ & $80.71 \pm 0.05^{\mathrm{d}}$ & $69.27 \pm 1.11^{\mathrm{g}}$ & $72.82 \pm 0.24^{\mathrm{f}}$ & $78.82 \pm 0.27^{\mathrm{e}}$ & $83.58 \pm 0.21^{\mathrm{c}}$ & $85.51 \pm 0.16^{\mathrm{b}}$ & $86.79 \pm 0.11^{\mathrm{a}}$ \\
$a^{*}$ & $1.27 \pm 0.03^{\mathrm{d}}$ & $2.98 \pm 0.10^{\mathrm{b}}$ & $3.74 \pm 0.31^{\mathrm{a}}$ & $1.59 \pm 0.08^{\mathrm{c}}$ & $0.80 \pm 0.07^{\mathrm{d}}$ & $0.24 \pm 0.05^{\mathrm{e}}$ & $-0.16 \pm 0.04^{\mathrm{f}}$ \\
$b^{*}$ & $18.26 \pm 0.05^{\mathrm{c}}$ & $20.88 \pm 0.49^{\mathrm{b}}$ & $22.24 \pm 1.09^{\mathrm{a}}$ & $22.41 \pm 0.09^{\mathrm{a}}$ & $20.04 \pm 0.26^{\mathrm{b}}$ & $20.58 \pm 0.19^{\mathrm{b}}$ & $21.73 \pm 0.16^{\mathrm{a}}$ \\
\hline
\end{tabular}

Results are means \pm standard deviation $(n=3)$. Values across rows followed by different letters are significantly different $(p<0.05)$. Distil: distill water $\mathrm{C}_{6} \mathrm{H}_{8} \mathrm{O}_{7}$ : citric acid and $\mathrm{Na}_{2} \mathrm{~S}_{2} \mathrm{O}_{7}$ : Sodium metabisulphite, $L^{*}$ : lightness, $a^{*}$ : redness $(+60) \&(-60)$ greenness and $b^{*}$ : yellowness $(+60) \&(-60)$ blueness.

$p<0.05$, ash content was significantly affected by sodium metabisulphite treatment and it increased as the concentration of sodium metabisulphite increased from 1.77 to $2.54 \%$. The increase in ash content might be due to diffusion of solutes from sodium metabisulphite solution to sweet potato slices during soaking. Ahmed et al. [8] observed similar results of ash content increase in pretreated sweet potato flour. However, citric acid did not significantly $(p>0.05)$ affect the ash content of untreated (control) and treated NSP flour samples. The low values of ash content on $15 \%$ sodium metabisulphite treated sample might be due to the leaching out of minerals during the pretreatment of NSP slices. Jangchud et al. [24] and Osundahunsi et al. [25] revealed that ash and protein contents of sweet potato flour are reduced by pretreatments involving leaching out such as blanching and parboiling. Both treatments did not significantly $(p<0.05)$ affect the protein content of NSP flour. Untreated sample (control) had the value of $2.64 \%$ while treated samples ranged from $2.54 \%$ to $2.82 \%$. This was lower than $5 \%$ which has been reported as the crude protein content of sweet potato flour [26,27]. However, the values are within the range of $1.0-8.5 \%$ as reported by Van Hal [1]. The decrease might be due to leaching out of nitrogenous substances during treatment. The results show that NSP flour can be used as a source of protein in rural communities to complement human diets since animal protein may be scarce or too expensive [28]. NSP flour had very little fat content. The untreated sample (control) had fat content of $0.69 \%$. This was similar to $0.65 \%$ which was reported by Eleazu and Ironua [11]. There was no significant $(p<0.05)$ difference in sodium metabisulphite treated samples. Ahmed et al. [8] also reported sodium metabisulphite to have no significant effects on the fat content of sweet potato flour. However, citric acid significantly $(p<0.05)$ affected the fat content of NSP flour and it ranged from highest $(0.68 \%)$ to lowest $(0.61 \%)$. This is similar to Haile et al. [19] observations who reported that the decrease in fat of sweet potato flour samples might be due to oxidation of fat triggered by citric acid.

The $\mathrm{pH}$ of a NSP flour suspension (Figure 2) is important because it affects most of the functional properties of the flour [11]. There was a significant difference $(p<0.05)$ in $\mathrm{pH}$ values of NSP flour. The values ranged from 5.09 to 6.42 . The untreated sample had a $\mathrm{pH}$ level of 6.05. A decrease in $\mathrm{pH}$ level was observed across the pretreatment concentration of sodium metabisulphite and citric acid which decreased from 6.42 to 5.82 and 5.64 to 5.09 respectively as concentration increased. Low $\mathrm{pH}$ values have been reported to be caused by high amylase activity which increases the level of acidity and this was similar to observations of Nabubuya et al. [29] who found the $\mathrm{pH}$ of creamed fleshed sweet potato flour to be 6.64. This was also in line with the observation of Haile et al. [19]. Citric acid had a greater effect on $\mathrm{pH}$ level of NSP flour compared to sodium metabisulphite because of its high acidity.

The results of colour measurement, as presented in Table 2 were significantly $(p<0.05)$ different in lightness $\left(L^{*}\right)$, redness $\left(a^{*}\right)$ and yellowness $\left(b^{*}\right)$ values for all pretreated flour samples. Sodium metabisulphite increased the lightness of the flour with an increase in concentration. The increase in the $L^{*}$ value might be due to the potential of the pretreatments to retard both enzymatic and nonenzymatic reactions in the sweet potato flour. Pretreatment such as sulphite and its salts are used to preserve the colour of fruits and vegetables because of their ability to retard the reactions of both enzymatic and nonenzymatic [30]. The increase in Lightness ( $L^{*}$ values) might also be due to oven drying temperature of the NSP since higher temperature inactivates phenolase enzyme. Phenolase activities have been reported to be deactivated at high temperatures [31]. Moreover, the reaction between sulphite ions and quinines inhibits phenolase activities in the flour and consumption of oxygen [1]. Ahmed et al. [8] also reported that sodium metabisulphite caused an increase in $L^{*}$ values of sweet potato flour. Compared to sodium metabisulphite, the $L^{*}$ values of citric acid treated samples were least ranging between 69.27 and 78.82 across all pretreatment concentration. Changes in carotenoids, oxidation, caramelisation, or phenolase [32] might have contributed to the decrease in $L^{*}$ values of the flour.

Conversely, the $b^{*}$ values for pretreated Ndou sweet potato flour was higher than the control sample in all pretreated concentration. However citric acid had a greater effect on this chroma than sodium metabisulphite. In citric acid and sodium metabisulphite, $b^{*}$ values increased as concentration level increased, ranging from 20.88 to 22.41 and 20.04 to 21.73 , respectively. High yellowness values in pretreated samples can be due to the higher amount of beta carotene in NSP flour [8, 30]. Beta-carotene is a very sensitive nutrient which degrades during processing or storage and this occurs via oxidation or isomeration [1]. NSP flour could add natural colour to food products. Results obtained for the measurement of redness represented by $a^{*}$ values indicated that redness $\left(a^{*}\right)$ was significantly $(p<0.05)$ affected by treatments. Sodium metabisulphite showed a decrease in redness values which ranged from 1.59 to -0.16 as concentration increased. A higher redness value of 3.74 was obtained at $10 \mathrm{~g} / \mathrm{L}$ of citric acid, showing a greater intensity of redness of the flour. The higher redness 


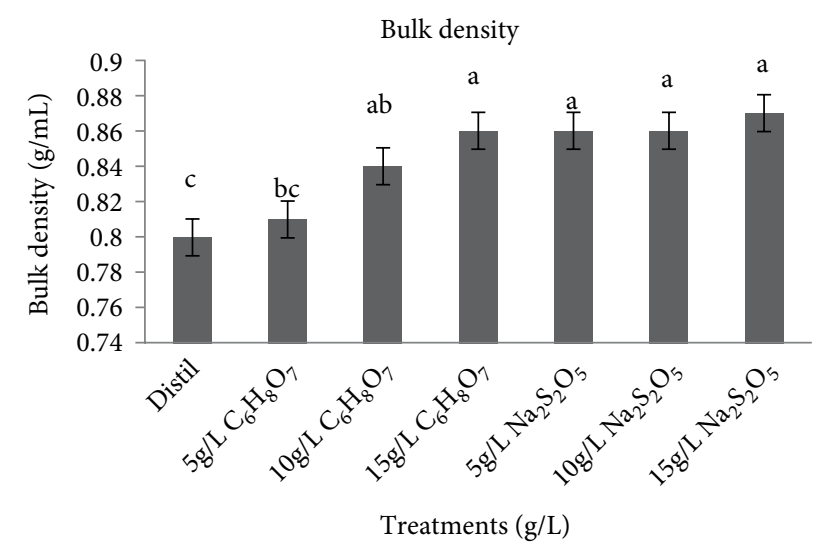

Bulk density

FIGURE 3: Effect of pretreatment on bulk density of Ndou sweet potato flour. Distil $=$ distilled water, $\mathrm{C}_{6} \mathrm{H}_{8} \mathrm{O}_{7}=$ citric acid and $\mathrm{Na}_{2} \mathrm{~S}_{2} \mathrm{O}_{7}=$ sodium metabisulphite.

value could be due to the presence of the anthocyanins pigments in the NSP flour since $\beta$-carotene is $6708 \mu \mathrm{g} / 100 \mathrm{~g}$ in fresh sweet potatoes while anthocyanin is $525 \mathrm{mg} / 100 \mathrm{~g}$ fresh weight (unpublished data) and it might also have been influenced by milling conditions and other contaminants $[1,33]$.

3.2. Functional Properties of NSP Flour. The bulk density (BD) of NSP flour is shown in Figure 3. BD measures the heaviness of a flour sample. It is a property that determines the porosity of a product which influences the design of the package and is also used to determine the type of packaging material and handling, especially production of flour in the food processing industry. The $\mathrm{BD}$ of the untreated NSP flour (control) was $0.80 \mathrm{~g} / \mathrm{ml}$ and it was generally high for the treated samples at different pretreatment concentration, ranging from $0.81 \mathrm{~g} / \mathrm{ml}$ to $0.87 \mathrm{~g} / \mathrm{ml}$. There was a significant difference $(p<0.05)$ in $\mathrm{BD}$ for all citric acid treated samples across all pretreatment concentrations while sodium metabisulphite did not have any significant difference $(p<0.05)$ with values ranging from 0.86 to $0.87 \mathrm{~g} / \mathrm{ml}$. This was similar to the value of $0.92 \mathrm{~g} / \mathrm{ml}$ obtained by Eleazu and Ironua in 2012 [11] for a cream fleshed sweet potato variety which is commercially sold in South Eastern Nigeria. The high BD of the NSP flour $(0.87 \mathrm{~g} / \mathrm{ml})$ as shown in Figure 3 indicates its heaviness. This means that it might be useful in food preparations to reduce paste thickness in food products, as well as in pharmaceuticals industry as a drug binder and disintegrant $[34,35]$.

The results of $\mathrm{BD}$ revealed that it depends on the particle size and initial moisture content of flours [36]. The increase observed in this study in $\mathrm{BD}$ is not desirable in packaging because higher density often results in reduced ability to compress the flour. This is unlikely to result in cost saving since more packaging materials would be required.

The water absorption capacity (WAC) of NSP flour is shown in Figure 4. Water absorption capacity is useful in determining the capacity of flour to take up water and swelling to improve uniformity in food. It is also advantageous in food processing for improving yield, uniformity, and giving shape to food products [25]. The WAC of pretreated sweet potato

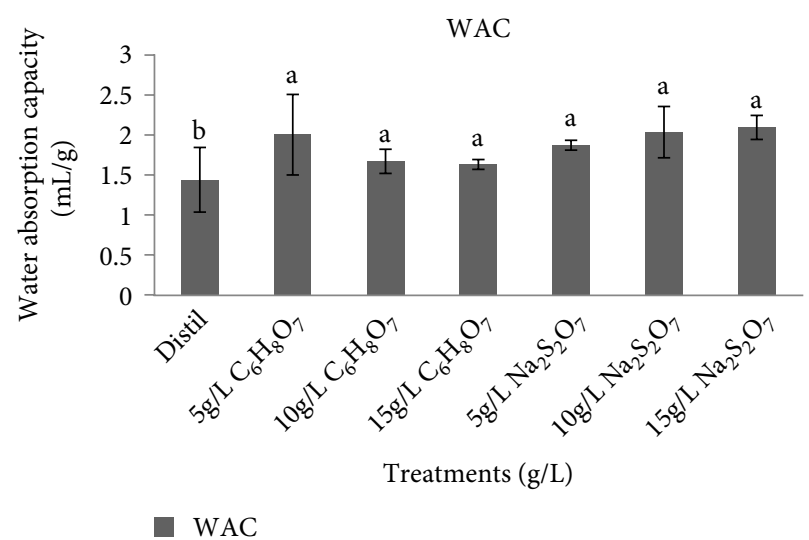

FIGURE 4: Effect of pretreatment on water absorption capacity of Ndou sweet potato flour. Distil= distilled water, $\mathrm{C}_{6} \mathrm{H}_{8} \mathrm{O}_{7}=$ citric acid and $\mathrm{Na}_{2} \mathrm{~S}_{2} \mathrm{O}_{7}=$ sodium metabisulphite.

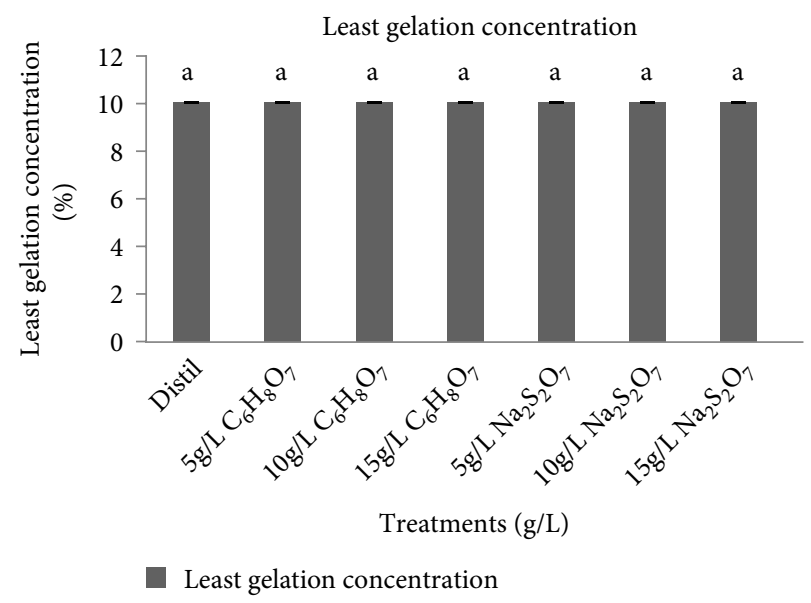

FIGURE 5: Effect of pretreatment on least gelation concentrantion of $\mathrm{Ndou}$ sweet potato flour. Distil = distilled water, $\mathrm{C}_{6} \mathrm{H}_{8} \mathrm{O}_{7}=$ citric acid and $\mathrm{Na}_{2} \mathrm{~S}_{2} \mathrm{O}_{7}=$ sodium metabisulphite.

flour samples was significantly $(p<0.05)$ higher than that of control samples $(1.44 \mathrm{ml} / \mathrm{g})$ which ranged from 1.63 to $2.03 \mathrm{ml} / \mathrm{g}$. The higher values of WAC recorded for the flour samples might have been caused by high polar amino acid residue of protein having affinity for water molecule [37]. Since they have hydrophilic parts such as polar or charged side chains, proteins and carbohydrates are the major chemical constituents that increase WAC of flours. The WAC of the NSP flours could also be influenced by increase in the solubility, leaching out of amylose, and loss of molecular structure of the starch as well as the crystalline structure [38].

The WAC might also be influenced by nonidentical structure of flours. The high WAC of sweet potato flours shows that they can be useful in the formulation of various foods such as meat sausage, bakery products, dough, and processed cheese [36].

Both pretreatments did not significantly $(p>0.05)$ affect the LGC of NSP flour as shown in Figure 5. This was similar to results obtained by Chandra et al. [36] on composite wheat 
TABLE 3: Viscosity, swelling power and solubility index of NSP flour.

\begin{tabular}{|c|c|c|c|c|c|c|c|}
\hline \multirow{3}{*}{ Functional properties } & \multicolumn{7}{|c|}{ Treatments $(\mathrm{g} / \mathrm{L})$} \\
\hline & \multirow{2}{*}{ Distil } & \multicolumn{3}{|c|}{$\mathrm{C}_{6} \mathrm{H}_{8} \mathrm{O}_{7}$} & \multicolumn{3}{|c|}{$\mathrm{Na}_{2} \mathrm{~S}_{2} \mathrm{O}_{7}$} \\
\hline & & 5 & 10 & 15 & 5 & 10 & 15 \\
\hline Viscosity (cP) & $26.2 \pm 0.61^{\mathrm{d}}$ & $33.3 \pm 0.62^{\mathrm{b}}$ & $36.4 \pm 0.62^{\mathrm{a}}$ & $29.1 \pm 0.60^{c}$ & $28.3 \pm 0.61^{\mathrm{c}}$ & $37.1 \pm 0.62^{\mathrm{a}}$ & $36.0 \pm 0.09^{\mathrm{a}}$ \\
\hline $\mathrm{SP}(\mathrm{g} / \mathrm{ml})$ & $7.18 \pm 1.61^{\mathrm{e}}$ & $8.47 \pm 1.82^{\mathrm{b}}$ & $9.59 \pm 0.51^{\mathrm{a}}$ & $6.30 \pm 0.41^{\mathrm{d}}$ & $8.05 \pm 1.21^{\mathrm{c}}$ & $7.77 \pm 0.22^{\mathrm{d}}$ & $7.57 \pm 0.91^{\mathrm{d}}$ \\
\hline $\mathrm{SI}(\mathrm{g} / \mathrm{ml})$ & $7.20 \pm 1.61^{\mathrm{e}}$ & $8.4 \pm 1.81^{\mathrm{b}}$ & $9.6 \pm 0.52^{\mathrm{a}}$ & $7.30 \pm 0.41^{\mathrm{d}}$ & $8.0 \pm 1.22^{\mathrm{b}}$ & $7.82 \pm 0.21^{\mathrm{c}}$ & $7.61 \pm 0.91^{\mathrm{d}}$ \\
\hline
\end{tabular}

Results are mean \pm standard deviation. Values in the same row followed by different letters are significantly different $(p<0.05)$. Distil: distill water, $\mathrm{C}_{6} \mathrm{H}_{8} \mathrm{O}_{7}=$ citric acid, $\mathrm{Na}_{2} \mathrm{~S}_{2} \mathrm{O}_{7}=$ sodium metabisulphite, $\mathrm{SP}=$ Swelling power and $\mathrm{SI}=$ solubility index.

TABLE 4: Thermal properties of NSP flour.

\begin{tabular}{|c|c|c|c|c|c|c|c|}
\hline \multirow{3}{*}{ Thermal properties $(\mathrm{g} / \mathrm{L})$} & \multicolumn{7}{|c|}{ Treatments } \\
\hline & \multirow{2}{*}{ Distil } & \multicolumn{3}{|c|}{$\mathrm{C}_{6} \mathrm{H}_{8} \mathrm{O}_{7}$} & \multicolumn{3}{|c|}{$\mathrm{Na}_{2} \mathrm{~S}_{2} \mathrm{O}_{7}$} \\
\hline & & 5 & 10 & 15 & 5 & 10 & 15 \\
\hline$T_{O}\left({ }^{\circ} \mathrm{C}\right)$ & $51.26 \pm 2.15^{\mathrm{d}}$ & $56.28 \pm 0.67^{\mathrm{c}}$ & $60.92 \pm 1.71^{b}$ & $57.81 \pm 1.91^{\mathrm{c}}$ & $63.40 \pm 1.06^{\mathrm{a}}$ & $58.12 \pm 2.02^{c}$ & $63.65 \pm 6.35^{\mathrm{a}}$ \\
\hline$T_{p}\left({ }^{\circ} \mathrm{C}\right)$ & $67.58 \pm 1.97^{\mathrm{d}}$ & $70.83 \pm 0.25^{\mathrm{b}}$ & $72.65 \pm 1.26^{\mathrm{b}}$ & $69.30 \pm 1.56^{\mathrm{c}}$ & $75.72 \pm 1.56^{\mathrm{a}}$ & $70.88 \pm 2.46^{\mathrm{b}}$ & $73.26 \pm 5.25^{\mathrm{a}}$ \\
\hline$T_{c}\left({ }^{\circ} \mathrm{C}\right)$ & $74.73 \pm 2.64^{c}$ & $84.35 \pm 0.46^{\mathrm{a}}$ & $85.38 \pm 1.05^{\mathrm{a}}$ & $77.58 \pm 3.56^{\mathrm{b}}$ & $85.28 \pm 5.60^{\mathrm{a}}$ & $83.17 \pm 3.14^{\mathrm{a}}$ & $81.38 \pm 2.86^{\mathrm{b}}$ \\
\hline$\Delta H(\mathrm{~J} / \mathrm{G})$ & $8.43 \pm 3.38$ & $12.78 \pm 0.23$ & $9.89 \pm 1.63$ & $10.05 \pm 2.14$ & $9.15 \pm 3.65$ & $9.63 \pm 2.94$ & $8.76 \pm 1.92$ \\
\hline
\end{tabular}

Results are mean \pm standard deviation. Values in the same row followed by different letters are significantly different $(p<0.05)$. Distil: distilled water, $\mathrm{C}_{6} \mathrm{H}_{8} \mathrm{O}_{7}$ = citric acid, $\mathrm{Na}_{2} \mathrm{~S}_{2} \mathrm{O}_{7}=$ sodium metabisulphite, $T_{O}$, Onset temperature, $T_{p}$, peak temperature, $T_{c}$, conclusion temperature, $\Delta H$, enthalpy of gelatinisation.

TABLE 5: Pearson correlation matrices between functional properties and physicochemical properties of NSP flour samples.

\begin{tabular}{|c|c|c|c|c|c|c|c|}
\hline & WAC & $\mathrm{pH}$ & $\mathrm{BD}$ & LGC & $L^{*}$ & $a^{*}$ & $b^{*}$ \\
\hline \multicolumn{8}{|l|}{ WAC } \\
\hline $\mathrm{pH}$ & 0.082 & & & & & & \\
\hline $\mathrm{BD}$ & 0.401 & -0.190 & & & & & \\
\hline LGC & -0.094 & $-0.606^{* *}$ & -0.129 & & & & \\
\hline $\mathrm{L}$ & 0.190 & 0.331 & $0.453^{*}$ & -0.265 & & & \\
\hline$a^{*}$ & -0.183 & -0.291 & $-0.458^{*}$ & 0.215 & $-0.997 * *$ & & \\
\hline $\mathrm{b}^{*}$ & 0.291 & 0.386 & -0.238 & 0.083 & -0.238 & 0.249 & \\
\hline
\end{tabular}

and sweet potato flours $(8-10 \%, \mathrm{w} / \mathrm{v})$ and Akubor [39] on pretreated yam flours $(8 \%, \mathrm{w} / \mathrm{v})$. However, all NSP flours are required to form a gel at low concentration $(10 \%, \mathrm{w} / \mathrm{v})$. The LGC for other flours such as safflower and maize [40] and plantain [39] were 8, 6, and 6 (w/v). The low LGC of some of these flours may be added as composite food for the curd formation or be used as additives to other food materials forming gel in food products. Better gelling ability of the protein ingredient requires lower LGC of the flour and this also results in increased swelling ability of the flour [41].

Akubor [39] reported that gelation capacity of flours is caused by protein concentration, particularly fraction of globulin, and interaction between proteins, carbohydrates, and lipids. Vautsinas and Nakai [42] reported that hydrophobicity and square of sulfhydryls of proteins significantly affect the protein gelation of the flour. The present study's LGC result shows that NSP flour can be useful as a thickening and gelling agent in food products such as sauce and puddings.
TABLE 6: Pearson correlation matrices of proximate composition of NSP flour samples.

\begin{tabular}{lcccc}
\hline & Fat & Ash & $M C$ & $P C$ \\
\hline Fat & & & & \\
Ash & -0.408 & & & \\
$M C$ & $0.728^{* *}$ & -0.075 & & \\
$P C$ & -0.107 & -0.170 & -0.106 & \\
\hline
\end{tabular}

${ }^{* *}$ Correlation is significant at the 0.01 level (2-tailed) and $*$ Correlation is significant at the 0.05 level (2-tailed). MC $=$ moisture content and $\mathrm{PC}=$ protein content.

Viscosity, swelling power, and starch solubility index of NSP flour are shown in Table 3. The viscosity of NSP flour samples ranged from 26.2 to $37.1 \mathrm{cP}$ with control and sodium metabisulphite pretreated sample at $10 \%$ having the lowest and highest values, respectively. Low molecular weight carbohydrates in the control sample might have contributed to reduced viscosity since they possess less 
TABLE 7: Pearson correlation matrices among proximate composition, physicochemical and functional properties of NSP flour samples.

\begin{tabular}{lccccccc}
\hline & WAC & $\mathrm{pH}$ & $\mathrm{BD}$ & LGT & $L^{*}$ & $a^{*}$ & $b^{*}$ \\
\hline Fat & -0.036 & $-0.556^{* *}$ & -0.269 & 0.381 & $-0.923^{* *}$ & $0.905^{* *}$ & 0.274 \\
Ash & -0.325 & -0.054 & $-0.436^{*}$ & -0.326 & $-0.574^{* *}$ & $0.603^{* *}$ & -0.076 \\
MC & 0.322 & -0.276 & -0.030 & 0.311 & $-0.536^{*}$ & $0.515^{*}$ & $0.733^{* *}$ \\
PC & -0.278 & -0.255 & -0.300 & $0.473^{*}$ & 0.214 & -0.254 & -0.161 \\
\hline **
\end{tabular}

${ }^{* *}$ Correlation is significant at the 0.01 level (2-tailed) and *Correlation is significant at the 0.05 level (2-tailed). WAC = water absorption capacity, $\mathrm{BD}=$ bulk density, PC: protein content, LGT $=$ least gelation concentration, $L^{*}=$ lightness, $a^{*}=$ redness and $b^{*}=$ yellowness.

water binding ability and may be more easily digested and absorbed as required by infants. Reduced viscosity in the control sample will be a good indicator for the appropriateness of a weaning food blend for infants [43]. The swelling power (SP) of pretreated NSP samples was significantly $(p<0.05)$ higher than that of control samples $(7.18 \mathrm{~g} / \mathrm{ml})$ which ranged from 8.47 to $7.57 \mathrm{~g} / \mathrm{ml}$ except for citric acid pretreated sample at $15 \%$ which had a lower value of $6.30 \mathrm{~g} / \mathrm{ml}$. Structural changes within the starch granules might be responsible for the increase in SC of pretreated samples [44]. When starch is gelatinised at a certain temperature, the molecular organisation is disrupted within the granules and the interactions between starch and water increase, resulting in a notable increase in the SP [45]. The presence of a large number of crystallites might have contributed to the low SP of citric acid pretreated sample at $15 \%$ since large crystallites increases granular stability thereby reducing the extent of granular swelling [46].

The decrease in SP could also be due to the interactions that might have occurred between amylose-amylose and amylo-pectin-amylopectin chains [44]. A low SP makes it more difficult for starch to be gelatinised since more mechanical energy is required to disrupt the crystallised areas of starch. The solubility index (SI) of pretreated NSP flours was significantly $(p<0.05)$ higher than that of control samples $(7.20 \mathrm{~g} / \mathrm{ml})$, ranging from 7.3 to $9.6 \mathrm{~g} / \mathrm{ml}$. The difference in the SI is related to the difference in the extent of starch degradation in NSP flour samples. High SI in pretreated samples could be due to high amount of amylose which leaches out easily during the swelling process [47]. At a higher SI such as in the sample pretreated with citric acid at $10 \%$, there is higher degradation of starch leading to more number of soluble molecules in the flour. Various factors such as source, SP, inter-associative forces within the amorphous, crystalline domains as well as presence of other components may influence solubility of starches in the flour [48].

Thermal properties of NSP flour are shown in Table 4. The onset temperature $\left(T_{0}\right)$, peak temperature $\left(T_{P}\right)$, conclusion temperature $\left(T_{c}\right)$, and gelatinization $\Delta H$ values of NSP flour samples are given in Table 3. The onset temperature $\left(T_{o}\right)$ ranges from 51.26 to $63.65^{\circ} \mathrm{C}$, peak temperature $\left(T_{p}\right)$ from 67.58 to $75.72^{\circ} \mathrm{C}$, conclusion temperature $\left(T_{c}\right)$ from 74.73 to $85.28^{\circ} \mathrm{C}$ and enthalpy of gelatinization $(\Delta H)$ from 8.48 to $12.78 \mathrm{~J} / \mathrm{g}$. A significant difference $(p<0.05)$ was observed in $T_{o}, T_{p}$, and $T_{c}$ and of pretreated and control NSP flour samples.

Low transition temperatures and $\Delta H$ values recorded in NSP flour samples might be attributed to large quantities of short amylopectin chains present in the starch of the flours
$[49,50]$ while slightly higher transition temperature values of the samples might be due to the contribution of heat-moisture treatment rather than pretreatments used in this study [51]. Shinoj et al. [52] reported that high transition temperatures are expected to result from a high degree of crystallinity, which impacts structural stability by making the starch granules more resistant to gelatinisation. This means that chemically pretreated NSP flour samples were more structurally stable and more resistant to gelatinisation. Both citric acid and sodium metabisulphite interacted with the matrix of NSP flour which caused a release of water and matric hardening resulting in a higher gelatinisation temperature.

3.3. Correlation of NSP Flour Samples. The correlation between functional and physicochemical properties of NSP flour is represented in Table 5. Lightness was positively correlated to WAC, BD pH and negatively correlated to LGC. This suggested that the higher the lightness of the flour, the higher WAC, BD, pH and the lower LGC it will have. The least gelation concentration was $99 \%$ which negatively correlated to $\mathrm{pH}$ level of NSP flour. Redness was observed to be negatively correlated to water absorption capacity, $\mathrm{pH}$ level, bulk density and lightness which means that as these parameters increase, redness decreases and vice versa. Yellowness of the flour was found to increase with an increase in WAC, $\mathrm{pH}$, redness and least gelation concentration and decrease with an increase in lightness and bulk density.

Correlation among proximate composition of NSP flour is shown in Table 6. The results show that ash content is inversely correlated to moisture content and also that there is $99 \%$ possibility that fat content increases with an increase in moisture content. Protein was negatively correlated to fat, ash and moisture content such that when those parameters increase, protein content decreases and vice versa. Ash and fat contents have also been found to be negatively correlated.

Correlation between proximate composition, physicochemical, and functional properties of NSP flour is shown in Table 7. The results show that fat content of the flour is negatively correlated to water absorption capacity, $\mathrm{pH}$ level, bulk density, and lightness. This means that flour with high fat content cannot hold high water as compared to the flour with low fat content. The results also show that protein content increases with a decrease in water absorption capacity, $\mathrm{pH}$ level, bulk density, redness, and yellowness of the flour. Ash content was $99 \%$ positively correlated to redness and negatively correlated yellowness of NSP flour. 


\section{Conclusions}

NSP flour was prepared by pretreating the tubers with citric acid and sodium metabisulphite at three different concentrations of 5,10 , and $15 \mathrm{~g} / \mathrm{L}$ for $10 \mathrm{~min}$. In the conversion of dried pretreated NSP slices to flour, citric acid had a significant effect on moisture, bulk density, $\mathrm{pH}$, and colour while sodium metabisulphite had a significant effect on moisture, ash, $\mathrm{pH}$, and colour. Both citric acid and sodium metabisulphite did not have any significant effects on protein, fat, water absorption capacity, and least gelation concentration. Pretreatments did improve physicochemical and functional properties of NSP flour. However, sodium metabisulphite was more effective than citric acid at $15 \mathrm{~g} / \mathrm{L}$. It is, therefore, recommended that a further study should be conducted on the effect of pretreatments on some bioactive compounds and other functional properties such as oil absorption capacity, emulsion activity, and foam capacity and stability of NSP flour.

\section{Data Availaibility}

The data used to support the findings of this study are available from the corresponding author upon request.

\section{Conflicts of Interest}

The authors declare that they have no conflicts of interest.

\section{References}

[1] M. V. Van Hal, "Quality of sweet potato flour during processing and storage," Food Review International, vol. 16, no. 1, pp. 1-37, 2000.

[2] N. M. Motsa, A. T. Modi, and T. Mabhaudhi, "Sweet potato (Ipomoea batatas L.) as drought tolerant and food security crop," South African Journal of Science, vol. 111, no. 11/12, p. 8, 2015.

[3] M. A. Akapapunam and D. A. Abiante, "Processing and quality evaluation of sweet potato chips," Plant Foods for Human Nutrition, vol. 41, no. 4, pp. 291-297, 1991.

[4] M. Ahmed, A. M. Sorifa, and J. B. Eun, "Peeling, drying temperatures, and sulphite-treatment affect physicochemical properties and nutritional quality of sweet potato flour," Food Chemistry, vol. 121, no. 1, pp. 112-118, 2010a.

[5] Y. Tang, W. Cai, and B. Xu, "Profiles of phenolics, carotenoids and antioxidative capacities of thermal processed white, yellow, orange and purple sweet potatoes grown in Guilin, China," Food Science and Human Wellness, vol. 4, no. 3, pp. 123-132, 2015.

[6] S. D. Wang, X. Pan, X. Lv et al., "Proteomic approach reveals that starch degradation contributes to anthocyanin accumulation in tuberous root of purple sweet potato," Journal of Proteomics, vol. 143, pp. 298-305, 2016.

[7] Y. Tanaka, N. Sasaki, and A. Ohmiya, "Biosynthesis of plant pigments: anthocyanins, betalains and carotenoids," The Plant Journal, vol. 54, no. 4, pp. 733-749, 2008.

[8] M. Ahmed, A. M. Sorifa, and J. B. Eun, "Effect of pretreatments and drying temperatures on sweet potato flour," International Journal of Food Science and Technology, vol. 45, no. 4, pp. 726$732,2010 \mathrm{~b}$.
[9] J. S. Utomo, Y. B. Cheman, R. A. Rahman, and M. S. Sadd, “The effect of shape, blanching methods and flour on characteristics of restructured sweet potato stick," International Journal of Food Science and Technology, vol. 43, no. 10, pp. 1896-1900, 2008.

[10] A. Mais and C. S. Brennan, "Characterisation of flour, starch and fibre obtained from sweet potato (Kumara) tubers and their utilization in biscuit production," International Journal of Food Science and Technology, vol. 43, no. 2, pp. 373-379, 2008.

[11] C. O. Eleazu and C. Ironua, "Physicochemical composition and antioxidant properties of a sweetpotato variety (Ipomoea batatas L.) commercially sold in South Eastern Nigeria," African Journal of Biotechnology, vol. 12, no. 7, pp. 720-727, 2013.

[12] AOAC, "Official methods of analysis of AOAC," Association of Official Analysis Chemists, 18th edition, AOAC International, Washington DC : USA, 2007.

[13] J. Vijayakumari, J. Mushtari-Begum, S. Begum, and S. Gokavi, "Sensory attributes of ethinic foods from finger millet (Eleusine coracana) recent trends in millet processing and utilization," in Proceeding of National Seminar on Processing and Utilization of Millet for Nutrition Security organized under RNPSI (NATP), CCSHAV, Hisar, pp. 7-12, 2003.

[14] G. I. Onwuka, "Food analysis and instrumentation," Theory and Practice. Napthali Prints, pp. 140-146, 2005.

[15] M. Konak, K. Carman, and C. Aydin, "Physical properties of chickpea seeds," Biosystems Engineering, vol. 82, no. 1, pp. 73-78, 2002.

[16] S. K. Sathe, S. S. Deshpande, and D. K. Salunke, "Functional properties of winged bean (Psophocarpus tetragonolobus L.) proteins," Journal of Food Science, vol. 47, no. 2, pp. 503-509, 1982.

[17] T. A. Anyasi, A. I. O. Jideani, and G. R. A. Mchau, "Effects of organic acid pre-treatment on microstructure, functional and thermal properties of unripe banana flour," Journal of Food Measurement and Characterization, vol. 11, no. 1, pp. 99-110, 2017.

[18] Q. Sun, M. Gong, Y. Li, and L. Xiong, "Effect of dry heat treatment on the physicochemical properties and structure of proso millet flour and starch," Carbohydrate Polymers, vol. 110, pp. 128-134, 2014.

[19] F. S. Haile, S. Admassu, and A. Fisseha, "Effects of pretreatments and drying methods on chemical composition, microbial and sensory quality of orange-fleshed sweet potato flour and porridge," American Journal of Food Technology, vol. 3, no. 3, pp. 82-88, 2015.

[20] A. S. Trejo-González, A. G. Loyo-González, and M. R. MunguíaMazariegos, "Evaluation of bread made from composite wheatsweet potato flours," International Food Research Journal, vol. 21, no. 4, pp. 1683-1688, 2014.

[21] J. Hayma, The Storage of Tropical Agricultural Products, Wageningen, Netherlands, Agromisa, 1995.

[22] Z. Chen, H. A. Schols, and A. G. J. Voragen, "Physicochemical properties of starches obtained from three varieties of chinese sweet potatoes," Journal of Food Science, vol. 68, no. 2, pp. 431-437, 2003.

[23] S. N. Moorthy, "Physicochemical and functional properties of tropical tuber starches," A Review Starch-Stärke, vol. 54, no. 12, pp. 559-592, 2002.

[24] K. Jangchud, J. Phimolsiripol, and V. Haruthaithanasan, "Physico-chemical properties of sweet potato flour and starch as affected by blanching and processing," Starch-Starke, vol. 55, no. 6, pp. 258-264, 2003. 
[25] O. F. Osundahunsi, T. N. Fagbemi, E. Kesselman, and E. Shimoni, "Comparison of physicochemical properties and pasting characteristics of flour and starch from red and white sweet potato cultivars," Journal of Agricultural and Food Chemistry, vol. 51, no. 8, pp. 2230-2236, 2003.

[26] J. H. Bradbury and W. D. Holloway, Chemistry of Tropical Root Crops, Australian Centre for International Agricultural Research, Canberra, Australia, pp. 101-119, 1988.

[27] J. A. Woolfe, Sweet Potato. An Untapped Food Resource, Cambridge University Press, p. 643, 1992.

[28] A. Colak, O. Faiz, and E. Sesli, "Nutritional composition of some wild edible mushrooms. Turk," Journal of Biochemistry, vol. 34, no. 1, pp. 25-31, 2009.

[29] A. Nabubuya, Y. B. Namutebi, J. Narvhus, and T. Wicklund, "Potential use of selected sweet potato (Ipomea batatas Lam) varieties as defined by chemical and flour pasting characteristics," Food and Nutrition Sciences, vol. 3, no. 7, pp. 889-896, 2012.

[30] Y. Li and M. Zhao, "Simple methods for rapid determination of sulfite in food products," Food Control, vol. 17, no. 12, pp. 975-980, 2006.

[31] A. Akyildiz and N. D. Ocal, "Effects of dehydration temperatures on colour and polyphenoloxidase activity of Amasya and Golden Delicious apple cultivars," Journal of the Science of Food and Agriculture, vol. 86, no. 14, pp. 2363-2368, 2006.

[32] A. A. Michael and P. W. Wilson, "Relationship between hunter colour values and b-carotene contents in white-fleshed African sweet potatoes (Ipomoea batatas Lam)," Journal of Agricultural and Food Chemistry, vol. 73, no. 3, pp. 301-306, 1997.

[33] B. J. Dobraszczyk, "Wheat and flour," in Cereals and Cereal Products, Chemistry and Technology, D. A. V. Dendy and B. J. Dobraszczyk, Eds., vol. 35, pp. 71-76, Aspen Publishers, Maryland, 2001.

[34] S. Chandra, S. Singh, and D. Kumari, "Evaluation of functional properties of composite flours and sensorial attributes of composite flour biscuits," Journal of Food Science and Technology, vol. 52, no. 6, pp. 3681-3688, 2015.

[35] S. G. Zaku, O. C. Aguzue, S. A. Thomas, and J. T. Barminas, "Studies on the functional properties and the nutritive quality of amura plant starch (Tacca involucrate) a wild tropical plant," African Journal of Food Science, vol. 3, no. 10, pp. 320-322, 2009.

[36] S. Chandra and S. Singh, "Assessment of functional properties of different flours," African Journal of Agricultural Research, vol. 8, no. 38, pp. 4849-4852, 2013.

[37] A. A. Yusuf, H. Ayedun, and L. O. Sanni, "Chemical composition and functional properties of raw and roasted Nigerian benniseed (Sesamum indicum) and Bambara groundnut (Vigna subterranea)," Food Chemistry, vol. 111, no. 2, pp. 277-282, 2008.

[38] J. M. Hashimoto and M. V. E. Grossman, "Effects of extrusion conditions on quality of cassava bran/cassava extrudates," International Journal of Food Science and Technology, vol. 38, no. 5, pp. 511-517, 2003.

[39] P. I. Akubor, F. A. Adamolekun, C. O. Oba, and I. T. Obari, "Chemical composition and functional properties of cowpea/ plantain flour blends cookie production," Plant Foods for Human Nutrition, vol. 58, no. 3, pp. 1-9, 2003.

[40] P. I. Akubor, "Chemical, functional and cookie baking properties of soybean/maize flour blends," Journal of Food Science and Technology, vol. 44, no. 6, pp. 619-622, 2007.
[41] P. Kaushal, V. Kumar, and H. K. Sharma, "Comparative study of physicochemical, functional, anti-nutritional and pasting properties of taro (Colocasia esculenta), rice (Oryza sativa), pegion pea (Cajanus cajan) flour and their blends," LWT-Food Science and Technology, vol. 48, no. 1, pp. 59-68, 2012.

[42] L. P. Vautsinas and S. Nakai, "A simple turbidimetric method of determining the fat binding capacity of protein," Journal of Agricultural and Food Chemistry, vol. 31, no. 1, pp. 58-63, 1993.

[43] M. A. Usman, M. K. Bolade, and S. James, "Functional properties of weaning food blends from selected sorghum [Sorghum bicolor (L.) Moench] varieties and soybean (Glycine max)," African Journal of Food Science, vol. 10, no. 8, pp. 112-121, 2016.

[44] O. O. Oyalinka, K. O. Adebowale, and B. I. Olu-Owolabi, "Effect of heat-moisture treatment on physicochemical properties of white sorghum starch," Food Hydrocolloids, vol. 22, no. 2, pp. 225-230, 2008.

[45] A. Gunaratne and R. Hoover, "Effect of heat-moisture treatment on the structure and physicochemical properties of tuber and root starches," Carbohydrate Polymers, vol. 49, no. 4, pp. 425437, 2002.

[46] Q. Liu, E. Weber, V. Currie, and R. Yada, "Physicochemical properties of starches during potato growth," Carbohydrate Polymer, vol. 51, pp. 213-221, 2003.

[47] L. O. Sanni, D. P. Ikuomola, and S. A. Sanni, "Effect of length of fermentation and varieties on the qualities of sweet potato gari," in Proc.8th triennial Symposium of the International Society for Tropical Root Crops. Africa Branch (ISTRC-AB), M. O. Akoroda, Ed., pp. 208-211, IITA, Ibadan, Nigeria, 2001.

[48] A. C. Kumoro, D. S. Retnowati, C. S. Budiyati, T. Manurung, and H. Siswanto, "Water solubility, swelling and gelatinization properties of raw and ginger oil modified gadung (Dioscoreahispida Dennst) flour," Research Journal of Applied Sciences, Engineering and Technology, vol. 4, no. 17, pp. 2854$2860,2012$.

[49] T. B. Tribess, J. P. Hernandez-Uribe, M. G. C. MendezMontealvo, E. W. Menezes, L. A. Bello-Perez, and C. C. Tadini, "Thermal properties and resistant starch content of green banana flour (Musa cavendishii) produced at different drying conditions," LWT - Food Science and Technology, vol. 42, no. 5, pp. 1022-1025, 2009.

[50] C. K. Reddy, S. Haripriya, and P. V. Vidya, "Morphology, physicochemical and functional characteristics of starches from different banana cultivars," Journal of Food Science and Technology, vol. 52, no. 11, pp. 7289-7296, 2015.

[51] A.-C. Eliasson and M. Gudmundsson, "Starch: Physicochemical and Functional Aspects," In Carbohydrates in Food, CRC Press, Boca RatonA.-C. Eliasson, Ed., pp. 411-415, 2nd edition, 2006.

[52] S. Shinoj, R. Viswanathan, M. S. Sajeev, and S. N. Moorthy, "Gelatinisation and rheological characteristics of minor millet flours," Biosystems Engineering, vol. 95, no. 1, pp. 51-59, 2006. 


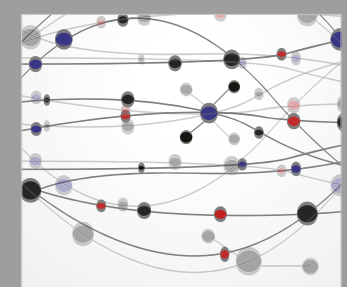

The Scientific World Journal
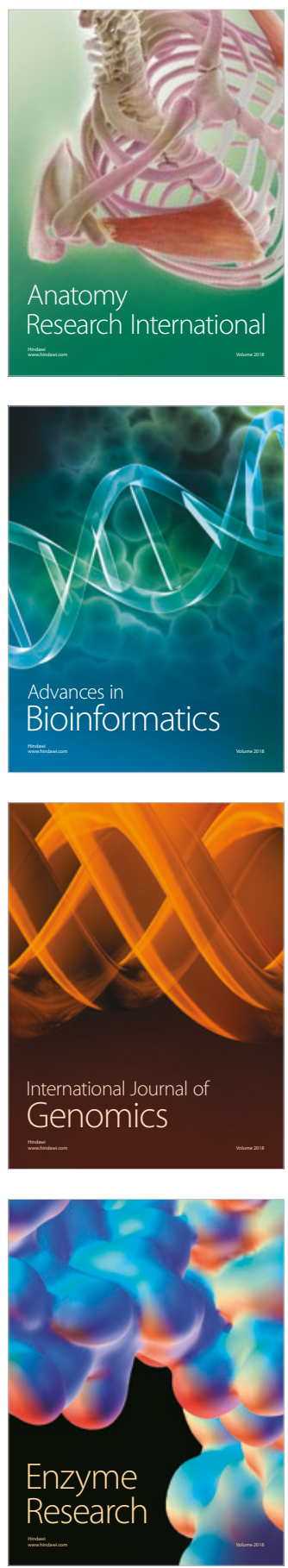
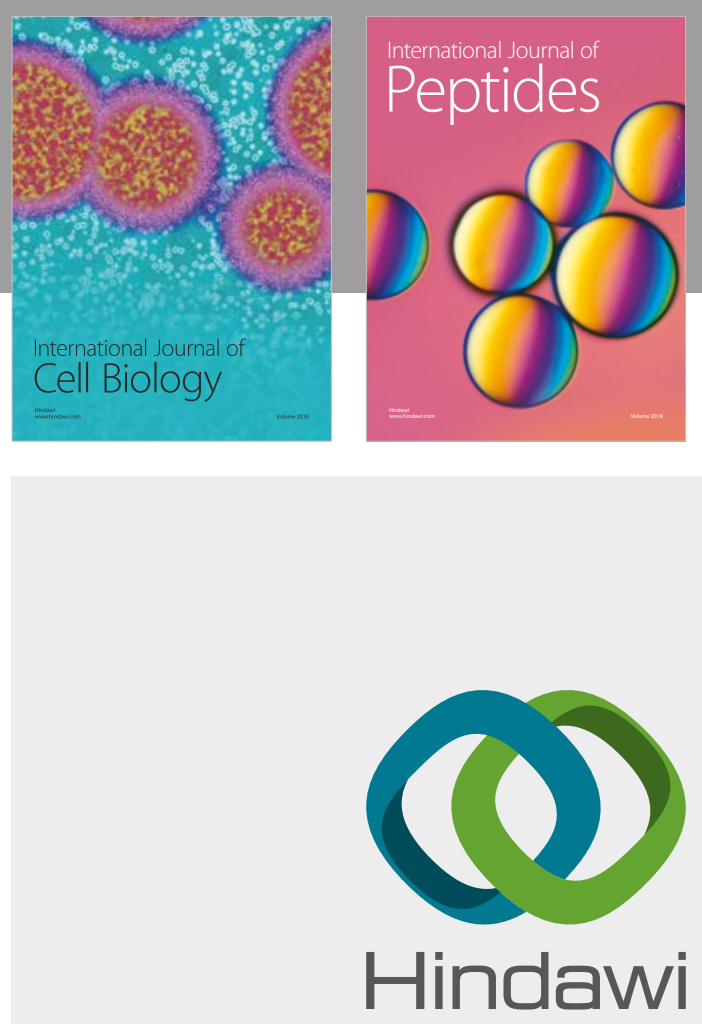

Submit your manuscripts at

www.hindawi.com
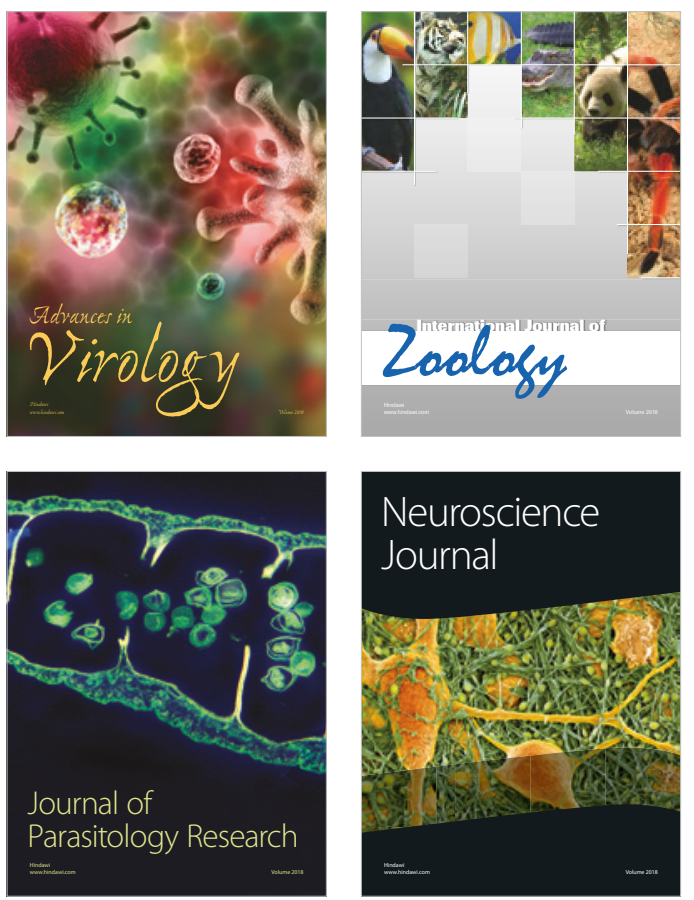
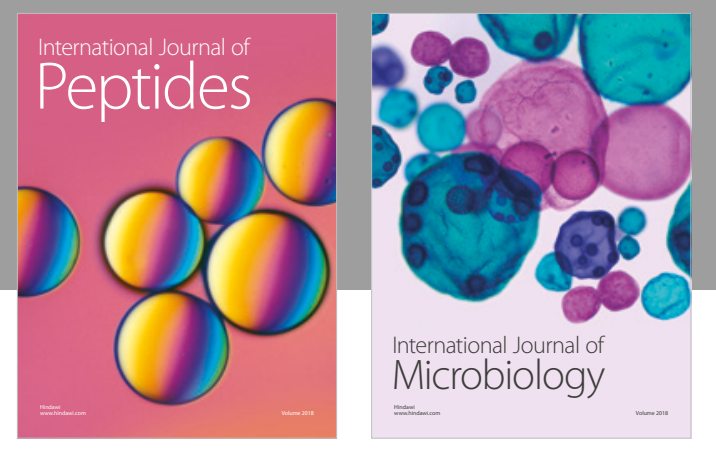

nternational Journal of Microbiology
Journal of
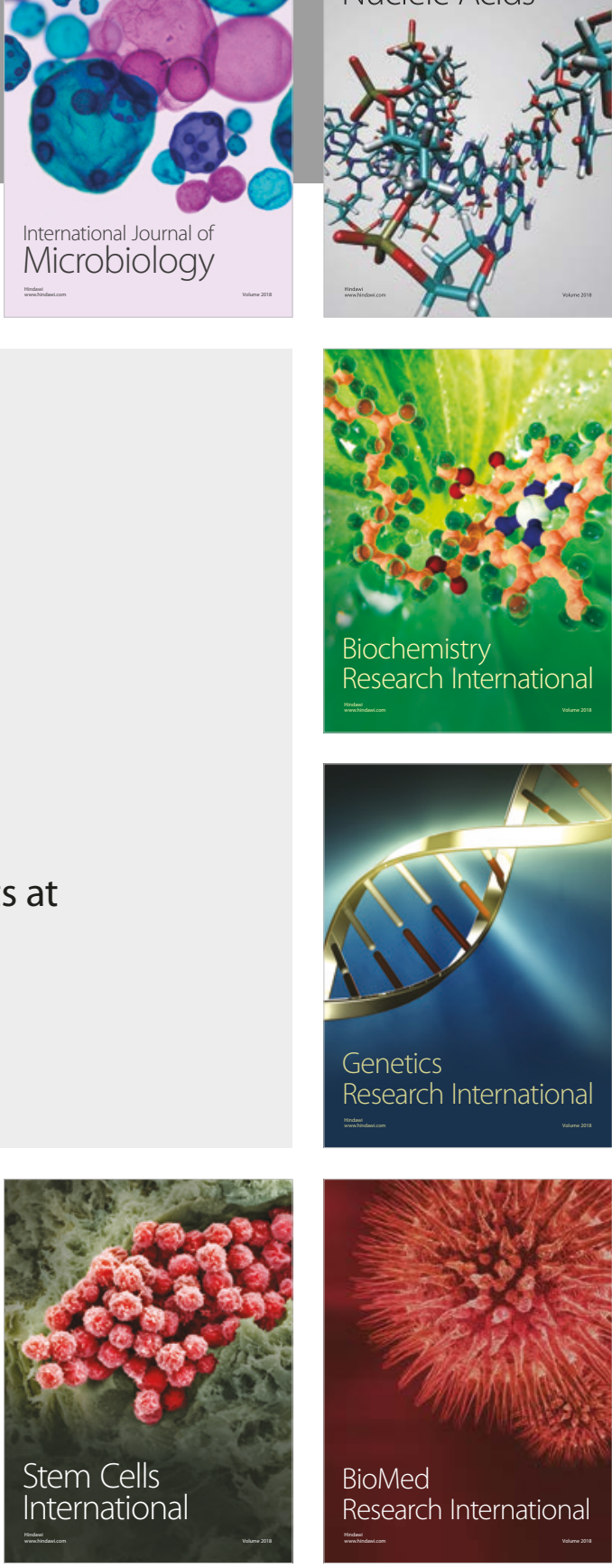
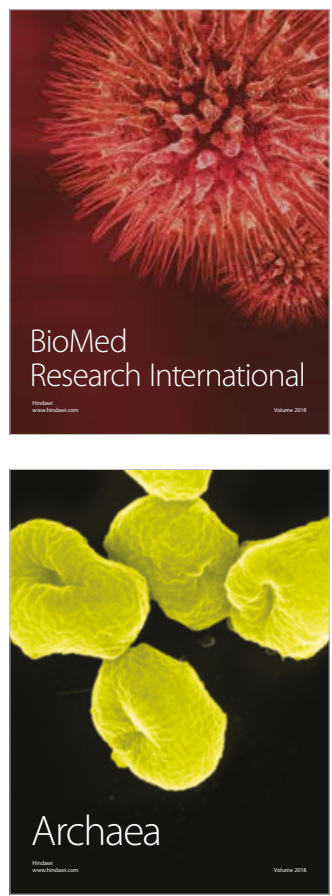